See discussions, stats, and author profiles for this publication at: https://www.researchgate.net/publication/324791375

\title{
Multi-proxy record of the Chicxulub impact at the Cretaceous-Paleogene boundary from Gorgonilla Island, Colombia
}

Article in Geology · April 2018

DOI: 10.1130/640224.1

CITATIONS

3

6 authors, including:

Ignacio Arenillas

University of Zaragoza

117 PUBLICATIONS 2,391 CITATIONS

SEE PROFILE

2. Vivi Vajda

Swedish Museum of Natural History

123 PUBLICATIONS 2,106 CITATIONS

SEE PROFILE
READS

603

- José Antonio Arz

1. University of Zaragoza

103 PUBLICATIONS 2,188 CITATIONS

SEE PROFILE

Vicente Gilabert

University of Zaragoza

17 PUBliCATIONS 5 CITATIONS

SEE PROFILE

Some of the authors of this publication are also working on these related projects:

Project Geology and stratigraphy of Cuba. Deposits of the K-Pg boundary. Fossil record of Cuba View project

Project Cretaceous/Paleogene boundary in Gorgonilla Island, Colombia, South America View project 


\title{
Multi-proxy record of the Chicxulub impact at the Cretaceous- Paleogene boundary from Gorgonilla Island, Colombia
}

\author{
Paul R. Renne ${ }^{1,2}$, Ignacio Arenillas ${ }^{3}$, José A. Arz ${ }^{3}$, Vivi Vajda ${ }^{4}$, Vicente Gilabert ${ }^{3}$, and Hermann D. Bermúdez \\ ${ }^{1}$ Berkeley Geochronology Center, Berkeley, California 94709, USA \\ 2Department of Earth and Planetary Science, University of California, Berkeley, California 94709, USA \\ ${ }^{3}$ Departamento de Ciencias de la Tierra, and Instituto Universitario de Investigación en Ciencias Ambientales de Aragón, \\ Universidad de Zaragoza, E-50009 Zaragoza, Spain \\ ${ }^{4}$ Swedish Museum of Natural History, Department of Palaeobiology, SE-104 05 Stockholm, Sweden \\ ${ }^{5}$ Grupo de Investigación Paleoexplorer, St. George, Vermont 05495, USA
}

\begin{abstract}
A $40 \mathrm{~m}$ stratigraphic section at Gorgonilla Island, Colombia, provides a unique deepmarine, low-latitude, Southern Hemisphere record of events related to the end-Cretaceous Chicxulub impact and the global Cretaceous/Paleogene boundary (KPB). The KPB is marked by a 20-mm-thick, densely packed spherule bed as defined by planktic foraminifera, in contrast to complex relationships found in high-energy, impact-proximal sites in the Gulf of Mexico and Caribbean basins. The absence of basal Danian foraminiferal Zone P0 may indicate a possible hiatus of $<\mathbf{1 0} \mathrm{ka}$ immediately above the spherule bed, but is most probably an artifact of deposition below the calcite compensation depth as suggested by the nearly complete absence of calcareous fossils for $20 \mathrm{~m}$ below the Zone $\mathrm{P} \alpha$. A weighted mean ${ }^{40} \mathrm{Ar} /{ }^{39} \mathrm{Ar}$ age of 66.051 \pm 0.031 Ma for 25 fresh glassy spherules unequivocally establishes both their derivation from Chicxulub, and the association between the impact and the KPB. The spherule bed, and Maastrichtian strata below it, display soft-sediment deformation features consistent with strong seismic motion, suggesting that seismic activity in the immediate aftermath of the Chicxulub impact continued for weeks. We discovered a fern-spike immediately above the spherule bed, representing the first record of this pioneer vegetation from the South American continent, and from a low-latitude (tropical) environment.
\end{abstract}

\section{INTRODUCTION}

The Chicxulub impact in the Yucatan Peninsula of Mexico deposited ejecta (e.g., iridium, shocked minerals, Ni-rich spinels and tektites) worldwide (Schulte et al., 2010). Large sedimentary disturbances, such as tsunamites and massive debris flows, are reported in the Gulf of Mexico, the Caribbean, and Atlantic continental margins (Claeys et al., 2002, and references therein). The thickness of the Chicxulub ejecta deposits and their deposition energy decrease with the distance from the impact site, which is consistent with Chicxulub as the unique source of ejecta material (Smit, 1999).

The age of the Chicxulub impact has remained controversial since Stinnesbeck et al. (2001) reported two to four altered impact glass spherule layers in the uppermost marly deposits of the Maastrichtian near La Sierrita, northeastern Mexico. According to Stinnesbeck et al. (2001), the older (primary) spherule layer is interpreted as to be located near the base of the planktic foraminifera Zone CF1 (Plummerita hantkeninoides), and it was thereby inferred that the Chicxulub impact predated the Cretaceous/ Paleogene boundary (KPB) by $300 \mathrm{ka}$. This interpretation was refuted by Soria et al. (2001), who showed that these layers in fact comprise one single spherule layer that is repeated and locally mixed with remobilized Maastrichtian marls due to slumping processes seismically induced by the Chicxulub impact.

The diverse interpretations arising from stratigraphic complexities in impact-proximal sites can be obviated to some extent by radioisotopic dating. Renne et al. (2013) presented ${ }^{40} \mathrm{Ar} /{ }^{39} \mathrm{Ar}$ data for an Ir-bearing KPB bed in Montana and fresh glassy tektites from Haiti that establish synchrony between the KPB and associated mass extinctions with the Chicxulub bolide impact to within $32 \mathrm{ka}$. However, unaltered tektite glasses linked to the Chicxulub impact have only been reported from proximal and/or intermediate areas such as Beloc (Haiti), where tektites are abundant, and El Mimbral and La Lajilla (northeastern Mexico), where preserved glassy spherules are scarce (Belza et al., 2015).

Although intense work has sought to identify Chicxulub impact ejecta on the South American continent (e.g., Gertsch et al., 2013, and references therein), the first tektite deposit connected to this impact was described by Bermúdez et al. (2016), who concluded that the spherule-bearing layer at Gorgonilla Island, Colombia, could have been deposited at any time within $200 \mathrm{ka}$ of the
KPB, which would permissibly support the persistent contention that the Chicxulub impact preceded the KPB by $>100$ ka (Stinnesbeck et al., 2001; Keller et al., 2007, and references therein). Here we present new micropaleontological data (planktic foraminifera and palynomorphs) and geochronological data $\left({ }^{40} \mathrm{Ar} /{ }^{39} \mathrm{Ar}\right)$ showing that the Gorgonilla spherule bed was synchronous with the KPB to within $\sim 10$ ka or less.

\section{GEOLOGIC CONTEXT}

The Gorgonilla section (Fig. 1) overlies mafic and ultramafic basement rocks that form part of the Caribbean plateau, generated by the present Galapagos hotspot in the mid Cretaceous (Kennan and Pindell, 2009). It was located at 2000-3000 km southwest of the Chicxulub crater and represents a bathyal depth deposit (Bermúdez et al., 2016). Exposed near the southern tip of Gorgonilla Island, the section comprises $\sim 40 \mathrm{~m}$ of interbedded tuffaceous sandstones and marls, with an 20-mm-thick bed of normal-size-graded spherules occurring in mid-section (Fig. 1A). Sediments underlying the spherule bed were affected by intense softsediment deformation and bed disruption (Fig. 1C), and provide evidence for syndepositional faulting, injectites, hydroplastic mixed layers, pillar and flame structures, small-scale slumping, and fault-graded beds; features typical of seismites (e.g., Montenat et al., 2007). These features are absent in strata overlying the spherule bed (Fig. 1B).

\section{NEW DATA AND THEIR IMPLICATIONS}

\section{${ }^{40} \mathrm{Ar} /{ }^{39} \mathrm{Ar}$ Geochronology}

We analyzed 25 spherules individually by incremental heating ${ }^{40} \mathrm{Ar} /{ }^{39} \mathrm{Ar}$ methods. Nineteen (19) of these yielded $100 \%$ concordant age plateaux, and the remainder yielded plateaux comprising $>85 \%$ of the ${ }^{39} \mathrm{Ar}$ released. For the six spherules displaying discordant age spectra, the discordance is due to anomalously young ages in the initial steps, which we interpret as 


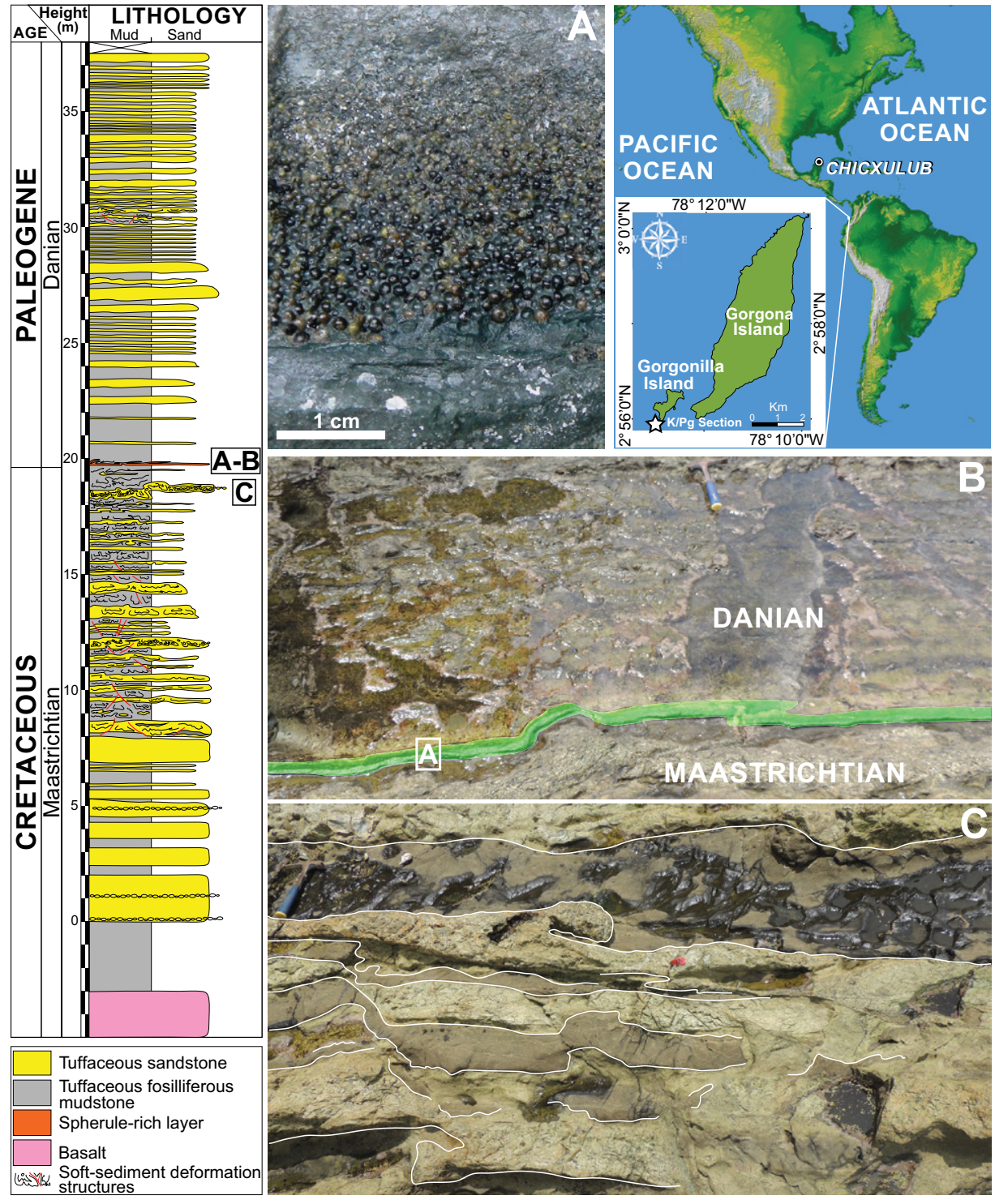

Figure 1. Location map and lithostratigraphy of the section at Gorgonilla Island, Colombia. Insets show details of spherule bed (A), Danian beds immediately above spherule bed (B, shaded green), and distorted Maastrichtian beds immediately below spherule bed (C). $\mathrm{K} / \mathrm{Pg}-$ Cretaceous/Paleogene boundary.

being due to post-formation alteration that was not mitigated during sample preparation. The weighted mean of all plateau ages is $66.051 \pm$ 0.031/0.054 Ma (Fig. 2). Ar isotope data are given in Table DR1 in the GSA Data Repository ${ }^{1}$.

As with the Haitian tektites, the $\mathrm{Ca} / \mathrm{K}$ values (derived from ${ }^{37} \mathrm{Ar} /{ }^{39} \mathrm{Ar}$ data) of Gorgonilla samples display a large range both between and within individual tektites. This is consistent with the observations of Bermúdez et al. (2016) from Gorgonilla, and of several electron probe microanalysis (EPMA) studies (Izett et al., 1991; Sigurdsson et al., 1991) of Haitian tektites, showing that individual tektites

${ }^{1}$ GSA Data Repository item 2018179, supplemental text, figures and tables, is available online at http://www.geosociety.org/datarepository/2018/ or on request from editing@geosociety.org. commonly contain mixtures of compositionally distinct glasses. Comparing plateau ages with integrated plateau values of $\mathrm{Ca} / \mathrm{K}$ shows no correlation, verifying that the spherules of diverse composition were cogenetic, and that the $\mathrm{Ca}$ interference corrections (for reactor-produced

The weighted mean plateau age of $66.051 \pm$ $0.031 \mathrm{Ma}$ is indistinguishable from that $(66.038$ $\pm 0.025 \mathrm{Ma}$ ) determined by three independent ${ }^{40} \mathrm{Ar} /{ }^{39} \mathrm{Ar}$ studies of the Haitian tektites (Renne et al., 2013). In view of the indistinguishable age and compositional similarities shown here and by Bermúdez et al. (2016), it is clear that the Gorgonilla tektites are cogenetic with the Haitian ones, and moreover, that they were produced by the Chicxulub impact dated at 66.030 $\pm 0.051 \mathrm{Ma}$ (Renne et al., 2013). Thus, we conclude that the Gorgonilla spherules are tektites ${ }^{36} \mathrm{Ar}$ and ${ }^{39} \mathrm{Ar}$ ) are accurate.

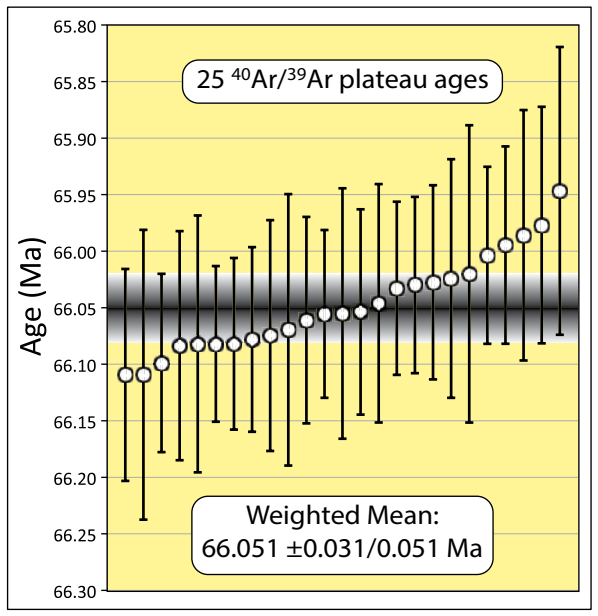

Figure 2. Rank order plot of ${ }^{40} \mathrm{Ar} /{ }^{39} \mathrm{Ar}$ plateau ages for individual spherules. The weighted mean is shown with uncertainty excluding/ including systematic sources.

unequivocally produced by the Chicxulub impact and represent the KPB, which has been dated at 66.043 $\pm 0.010 \mathrm{Ma}$ (Sprain et al., 2015). All of these relevant ages are based on ${ }^{40} \mathrm{Ar} /{ }^{39} \mathrm{Ar}$ dating using the same calibration (see the Data Repository); hence, meaningful comparison requires neglecting systematic uncertainties such as those arising from decay constants and the age of the standard. The maximum age difference between any two of these ages is $21 \pm$ $60 \mathrm{ka}$; i.e., they are all indistinguishable within uncertainties.

\section{Micropaleontology}

The abundance of radiolarians and siliceous sponge spicules in the Gorgonilla section contrasts with the absence of planktic foraminifera tests within and below the deformed tektite bed, except for very scarce specimens of Heterohelix globulosa, Pseudotextularia elegans, Gublerina cuvillieri, Globigerinelloides praevolutus, Rugoglobigerina rugosa, and Pseudoguembelina palpebra identified in samples 15.30 and 11.20 (Fig. DR1 and Table DR2). These species are known from the Campanian to the KPB, but P. palpebra is restricted to the Maastrichtian, from 71.75 to 66.04 Ma according to the Geologic Time Scale 2012 (GTS2012; Gradstein et al., 2012).

Bermúdez et al. (2016) assigned the $25 \mathrm{~cm}$ below the spherule layer to the Zone CF1, which spans the last $140 \mathrm{ka}$ of the Cretaceous (Husson et al., 2014). However, we have not found specimens of $P$. hantkeninoides, the index species for Zone CF1. Scarcity of planktic foraminifera, absence of index species, and intense soft-sediment deformation affecting the sediments underlying the tektite bed hamper high-resolution age assessment of the Maastrichtian interval.

In the Danian, there are planktic foraminifera only in the first meter above the spherule bed, and the taxa identified belong to Zone P $\alpha$ 
(basal Danian) following the zonation scheme of Berggren and Pearson (2005) (Fig. 3). The basal assemblage identified includes species such as Parvularugoglobigerina longiapertura, and Guembelitria cretacea, distinctive of the lower part of the Zone P $\alpha$. The youngest assemblage identified (in sample 21.10), which includes $P$. eugubina and Eoglobigerina simplicissima (Fig. 3; Table DR2), is characteristic of the upper part of the Zone P $\alpha, \sim 50-60$ ka younger than the KPB event according to the biochronological scale of Arenillas et al. (2004). The basal Danian biozone (Zone P0 of Berggren and Pearson, 2005) has not been identified in the Gorgonilla section. However, a bloom of the opportunistic genus Guembelitria s.l. was identified in sample 19.98 at $5 \mathrm{~cm}$ above the top of the spherule bed (Fig. 3; Table DR2). This bloom corresponds to the Planktic Foraminiferal Acme Stage 1 (PFAS-1) of Arenillas et al. (2006), and is followed immediately by a second bloom of Parvularugoglobigerina s.1., corresponding to PFAS-2 of Arenillas et al. (2006). Collectively, the absence of a diagnostic P0 assemblage but the presence of PFAS-1 suggests a possible hiatus of no more than $10 \mathrm{ka}$.

\section{Palynology}

The palynological residues include abundant pyrite crystals but are poor in organic matter. Most samples include green algal colonies, but no other palynomorphs are encountered below the spherule bed. Although the Maastrichtian samples are devoid of pollen and spores, fern spores are notably present in the samples above the spherule bed (Fig. DR2; Table DR3). Fern spores first occur in sample 19.86, only $1 \mathrm{~cm}$ above the spherule layer, where they are represented by sparse Cyathidites minor. A more diverse assemblage is recorded $12 \mathrm{~cm}$ above the spherule layer, from sample 20.05, where Cyathidites australis, C. minor, Gleicheniidites circinidites, Cibotiidites tuberculiformis, Deltoidospora toralis, and the angiosperm pollen Tricolpites reticulatus co-occur, indicating the presence of an advanced pioneer succession (Fig. DR2). Fern spores occur consistently and dominate the assemblages above the spherule bed. The aquatic fern Azolla, represented by both massulae and microspores, appears above the spherule layer in sample 20.15 .

\section{DISCUSSION AND CONCLUSIONS}

${ }^{40} \mathrm{Ar} /{ }^{39} \mathrm{Ar}$ dating and planktic foraminiferal assemblages clearly indicate that the Gorgonilla section records deposition of tektites derived from the Chicxulub impact in a relatively complete section with a possible hiatus of $<10 \mathrm{ka}$ following the KPB. The absence of foraminifera in the basal $5 \mathrm{~cm}$ above the spherule bed suggests deposition below the calcite compensation depth (CCD) (as with the Maastrichtian beds), preventing the identification of the Zone P0. Preserved planktic foraminiferal assemblages confined to the Zone P $\alpha$ in Gorgonilla section may be a consequence of the rapid and pronounced deepening of the local CCD, during a period of ocean alkalinity build-up and $\mathrm{CaCO}_{3}$ preservation that was globally enhanced following the Chicxulub impact (e.g., Henehan et al., 2016).

Deposition of the tektites was closely synchronous with ongoing seismic activity. Given the probable flight time (minutes to tens of minutes; Alvarez et al., 1995) of tektites deposited $>2000 \mathrm{~km}$ from their source, and a minimum settling time of $\sim 550 \mathrm{~s}$ estimated for 2 $\mathrm{km}$ water depth, it is unlikely that the seismic activity affecting the spherule bed records the initial ground motion from the impact. A seismic wave propagation velocity of $2-5 \mathrm{~km} / \mathrm{s}$ implies a delay of only 400-1000 s between the impact and the onset of ground motion at Gorgonilla, by which time the tektites would not have been deposited. Thus, it follows that strong seismicity was ongoing episodically for at least several tens of minutes following the impact, consistent with the inference of Norris and Firth (2002) of seismically induced mass wasting around the Atlantic margin for weeks after the impact. The presence of in situ deformed sediments in northern South America strengthens the evidence that

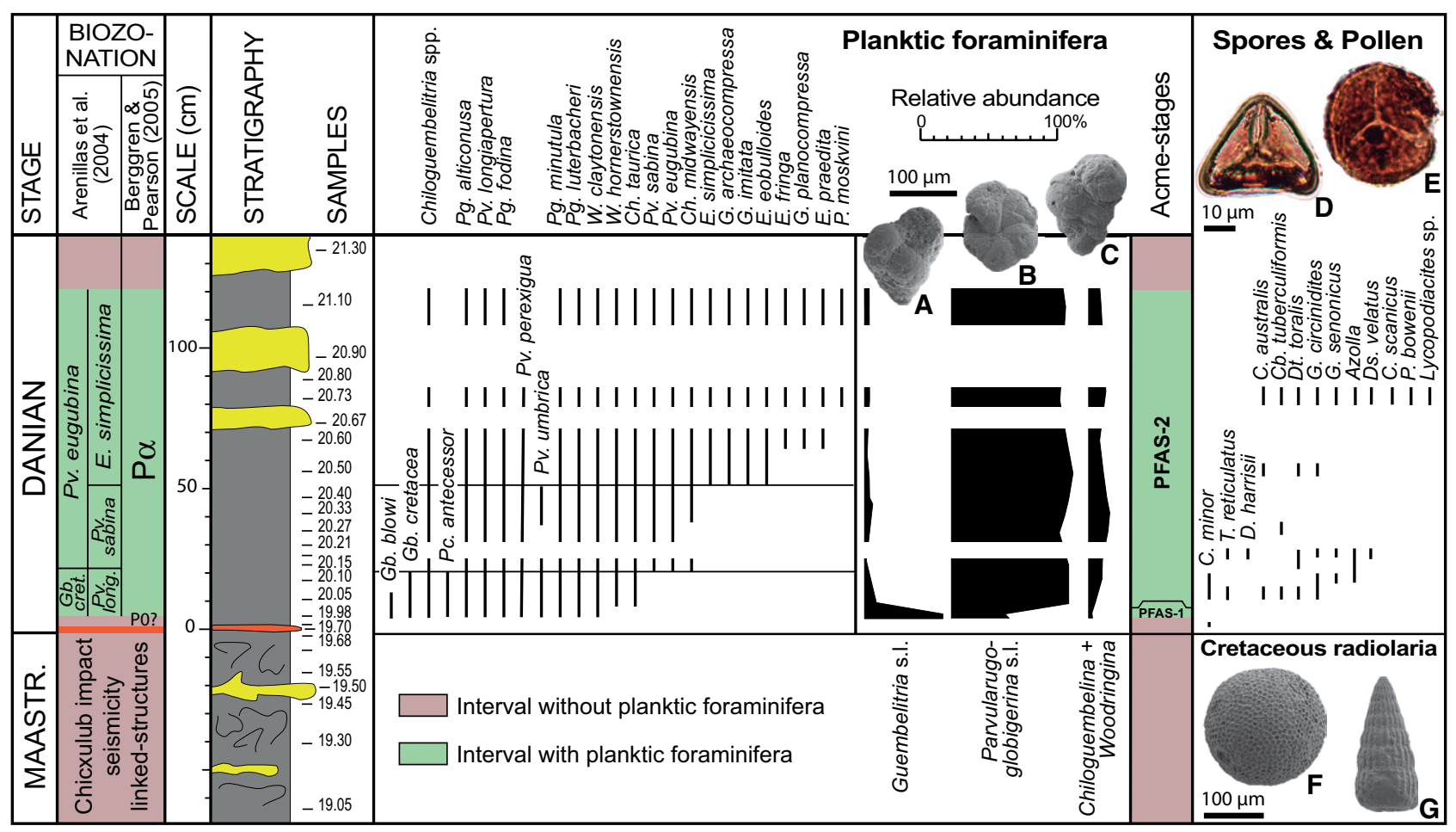

Figure 3. Stratigraphic ranges of planktic foraminifera, spores and pollen, and planktic foraminiferal acme-stages (PFAS). Guembelitria s.I. includes Guembelitria and Chiloguembelitria species, and Parvularugoglobigerina s.l. includes Parvularugoglobigerina and Palaeoglobigerina species. MAASTR.-Maastrichtian, Gb. cret.-Guembelitria cretacea, Pv. long.-Parvulorugoglobigerina longiapertura, P $\alpha$ and P0-foraminiferal zones, PFAS_Planktic Foraminiferal Acme Stage. Planktic foraminifera abbreviations: Gb.-Guembelitria, Pc.-Pseudocaucasina, Pg._Palaeoglobigerina, Pv._Parvulorugoglobigerina, W.-Woodringina, Ch.-Chiloguembelina, E.-Eoglobigerina, G.-Globalomalina, P.Parasubbotina. Spores and pollen abbreviations: C.-Cyathidites, T.-Tricolpites, D.-Dictyophyllidites, Cb.-Cibotiidites, Dt.-Deltoidospora, G.-Gleicheniidites, Ds.—Densoisporites, Cg.-Cingutriletes, P.—Peromonolites. 
seismic shaking generated by the impact, and possible aftershocks, represents a major geological event that affected uppermost Maastrichtian sediments over a vast region (Smit, 1999).

The results and interpretation of the planktic foraminiferal record are supported by the terrestrial palynological record, which represents the first evidence of a "fern-spike" following the Chicxulub impact from a tropical habitat. The fern spores, which only occur above the KPB at Gorgonilla, are represented by both ground ferns and tree ferns and, in some samples, also by water ferns (Azolla). The genus Azolla consistently characterizes warm-climate lacustrine environments, and first appears in the geological record in Lower Cretaceous successions (Vajda and McLoughlin 2005). Aquatic ferns such as Azolla can reproduce asexually through vegetative regeneration in association with nitrogen-fixing cyanobacterial symbionts, which occurred in abundance in the post-impact environment, providing advantages in the aftermath of the KPB and highlighting their potential to endure altered environmental conditions. Fern spikes are so far known only from highpaleolatitude sites (Vajda et al., 2001; Schulte et al., 2010, and references therein),

Importantly, the general characteristic of the latest Maastrichtian and Paleogene pollen and spore assemblages of paleotropical Colombia, Bolivia, Brazil, and Venezuela is the predominance of angiosperm pollen grains, whereas fern spores are extremely sparse (Jaramillo et al., 2007, and references therein). The fern-spore dominance in the Gorgonilla samples suggests that a fundamental change in local paleogeography occurred coincident with the Chicxulub impact, possibly a result of rapid, seismically induced tectonic emergence of nearby landmasses that were quickly colonized by ferns.

\section{ACKNOWLEDGMENTS}

We thank D. Mark, C. Lowery, and P. Claeys for their constructive reviews. Renne was supported by the Ann and Gordon Getty Foundation. This study is a contribution to project CGL2015-64422-P (MINECO/ FEDER-UE, Spanish Ministry of Economy, Industry and Competitiveness and the European Fund for Regional Development). Gilabert acknowledges support from the MINECO/FEDER-UE (FPI grant BES-2016-077800). Vajda was supported by the Swedish Research Council (VR grant 2015-4264, and LUCCI, Lund University Carbon Cycle Centre). We thank Paleoexplorer SAS (Colombia) for logistics and fieldwork support, and Parques Nacionales Naturales de Colombia, especially M.X. Zorrilla and L.F. Payán, for support during 2014-2015 geological campaigns.

\section{REFERENCES CITED}

Alvarez, W., Claeys, P., and Kieffer, S.W., 1995, Emplacement of Cretaceous-Tertiary boundary shocked quartz from Chicxulub crater: Science, v. 269, p. 930-935, https://doi.org/10.1126 /science.269.5226.930.

Arenillas, I., Arz, J.A., and Molina, E., 2004, A new high-resolution planktonic foraminiferal zonation and subzonation for the lower Danian: Lethaia, v. 37, p. 79-95, https://doi.org/10.1080 /00241160310005097.

Arenillas, I., Arz, J.A., Grajales-Nishimura, J.M., Murillo-Muñetón, G., Alvarez, W., CamargoZanoguera, A., Molina, E., and RosalesDomínguez, C., 2006, Chicxulub impact event is Cretaceous/Paleogene boundary in age: New micropaleontological evidence: Earth and Planetary Science Letters, v. 249, p. 241-257, https:// doi.org/10.1016/j.eps1.2006.07.020.

Belza, J., Goderis, S., Smit, J., Vanhaecke, F., Baert, K., Terryn, H., and Claeys, P., 2015, High spatial resolution geochemistry and textural characteristics of "microtektite" glass spherules in proximal Cretaceous-Paleogene sections: Insights into glass alteration pattern and precursor melt lithologies: Geochimica et Cosmochimica Acta, v. 152, p. 1-38, https://doi.org/10.1016/j .gca.2014.12.013.

Berggren, W.A., and Pearson, P.N., 2005, A revised tropical to subtropical Paleogene planktonic foraminiferal zonation: Journal of Foraminiferal Research, v. 35, p. 279-298, https://doi.org/10.2113 135.4.279.

Bermúdez, H.D., García, J., Stinnesbeck, W., Keller, G., Rodrígez, J.V., Hanel, M., Hopp, J., Schwarz, W.H., Trieloff, M., Bolivar, L., and Vega, F.J., 2016, The Cretaceous-Palaeogene boundary at Gorgonilla Island, Colombia, South America: Terra Nova, v. 28, p. 83-90, https://doi.org /10.1111/ter.12196.

Claeys, P., Kiessling, W., and Alvarez, W., 2002, Distribution of Chicxulub ejecta at the CretaceousTertiary boundary, in Koeberl, C., and MacLeod, K. G.,eds., Catastrophic Events and Mass Extinctions: Impacts and Beyond: Geological Society of America Special Papers, v. 356, p. 55-68. https:// doi.org/10.1130/0-8137-2356-6.55.

Gertsch, B., Keller, G., Adatte, T., and Berner, Z., 2013, The Cretaceous-Tertiary boundary (KTB) transition in NE Brazil: Journal of the Geological Society, v. 170, p. 249-262, https://doi.org/10 $.1144 /$ jgs2012-029.

Gradstein, F.M., Ogg, J.G., Schmitz, M., and Ogg, G., 2012, The Geologic Time Scale 2012: Amsterdam, Elsevier, $1176 \mathrm{p}$.

Henehan, M.J., Hull, P.M., Penman, D.E., Rae, J.W.B., and Schmidt, D.N., 2016, Biogeochemical significance of pelagic ecosystem function: an endCretaceous case study: Philosophical Transactions of the Royal Society of London, Series B, Biological Sciences, v. 371, p. 20150510, https:// doi.org/10.1098/rstb.2015.0510.

Husson, D., Galbrun, B., Gardin, S., and Thibault, N., 2014, Tempo and duration of short-term environmental perturbations across the Cretaceous-Paleogene boundary: Stratigraphy, v. 11, p. 159-171.

Izett, G.A., Dalrymple, G.B., and Snee, L.W., 1991, ${ }^{40} \mathrm{Ar} /{ }^{39} \mathrm{Ar}$ Age of Cretaceous-Tertiary Boundary Tektites from Haiti: Science, v. 252, p. 1539-1542, https://doi.org/10.1126/science.252.5012.1539.

Jaramillo, C.A., Bayona, G., Pardo-Trujillo, A., Rueda, M., Torres, V., Harrington, G.J., and Mora, G., 2007, The palynology of the Cerrejón Formation (Upper Paleocene) of northern Colombia: Palynology, v. 31, p. 153-189, https://doi.org/10 .2113 /gspalynol.31.1.153.

Keller, G., Adatte, T., Berner, Z., Harting, M., Baum, G., Prauss, M., Tantawy, A., and Stüben, D., 2007, Chicxulub impact predates K-T boundary: New evidence from Brazos, Texas: Earth and Planetary Science Letters, v. 255 , p. 339-356, https://doi .org/10.1016/j.epsl.2006.12.026.

Kennan, L., and Pindell, J.L., 2009, Dextral shear, terrane accretion and basin formation in the
Northern Andes: Best explained by interaction with a Pacific-derived Caribbean Plate, in James, K.H., et al., eds., Origin and Evolution of the Caribbean Plate: Geological Society of London Special Publications, v. 328, p. 487-531, https:// doi.org/10.1144/SP328.20.

Montenat, C., Barrier, P., Ott d'Estevou, P., and Hibsch, C., 2007, Seismites: An attempt at critical analysis and classification: Sedimentary Geology, v. 196, p. 5-30, https://doi.org/10.1016/j .sedgeo.2006.08.004.

Norris, R.D., and Firth, J., 2002, Mass wasting of Atlantic continental margins following the Chicxulub impact event, in Koeberl, C., and MacLeod, K. G., eds., Catastrophic Events and Mass Extinctions: Impacts and Beyond: Geological Society of America Special Papers, v. 356, p. 79-95, https:// doi.org/10.1130/0-8137-2356-6.79.

Renne, P.R., Deino, A.L., Hilgen, F.J., Kuiper, K.F., Mark, D.F., Mitchell, W.S., Morgan, L.E., Mundil, R., and Smit, J., 2013, Time scales of critical events around the Cretaceous-Paleogene boundary: Science, v. 339, p. 684-687, https://doi.org /10.1126/science.1230492.

Schulte, P., et al., 2010, The Chicxulub asteroid impact and mass extinction at the Cretaceous-Paleogene boundary: Science, v. 327, p. 1214-1218, https:// doi.org/10.1126/science.1177265.

Sigurdsson, H., D’Hondt, S., Arthur, M.A., Bralower, T.J., Zachos, J.C., van Fossen, M., and Channell, J.E.T., 1991, Glass from the Cretaceous/Tertiary boundary in Haiti: Nature, v. 349, p. 482-487, https://doi.org/10.1038/349482a0.

Smit, J., 1999, The global stratigraphy of the Cretaceous-Tertiary Boundary impact ejecta: Annual Review of Earth and Planetary Sciences, v. 27, p. $75-113$, https://doi.org/10.1146/annurev.earth .27.1.75.

Soria, A.R., Liesa, C., Mata, M.P., Arz, J.A., Alegret, L., Arenillas, I., and Meléndez, A., 2001, Slumping and a sandbar deposit at the Cretaceous-Tertiary boundary in the El Tecolote section (northeastern Mexico): An impact-induced sediment gravity flow: Geology, v. 29, p. 231-234, https:// doi.org/10.1130/0091-7613(2001)029<0231: SAASDA $>2.0 . C O ; 2$.

Sprain, C.J., Renne, P.R., Wilson, G.P., and Clemens, W., 2015, High-resolution chronostratigraphy of the terrestrial Cretaceous-Paleogene transition and recovery interval in the Hell Creek region, Montana: Geological Society of America Bulletin, v. 127, p. 393-409, https://doi.org/10.1130 /B31076.1.

Stinnesbeck, W., et al., 2001, Late Maastrichtian age of spherule deposits in northeastern Mexico: Implication for Chicxulub scenario: Canadian Journal of Earth Sciences, v. 38, p. 229-238, 10 .1139/e00-061.

Vajda, V., and McLoughlin, S., 2005, A new Maastrichtian-Paleocene Azolla species from Bolivia, with a comparison of the global record of coeval Azolla microfossils: Alcheringa, v. 29, p. 305-329, https://doi.org/10.1080/03115510508619308.

Vajda, V., Raine, J.I., and Hollis, C.J., 2001, Indication of global deforestation at the Cretaceous-Tertiary boundary by New Zealand fern spike: Science, v. 294 , p. 1700-1702, https://doi.org/10.1126 /science.1064706.

Manuscript received 1 March 2018

Revised manuscript received 10 April 2018

Manuscript accepted 13 April 2018

Printed in USA 